This Accepted Author Manuscript is copyrighted and published by Elsevier. It is posted here by agreement between Elsevier and University of Brasilia. Changes resulting from the publishing process - such as editing, corrections, structural formatting, and other quality control mechanisms - may not be reflected in this version of the text. The definitive version of the text was subsequently published in [Micron, Volume 40, Issue 4, June 2009, Pages 419-425, doi:10.1016/j.micron.2009.02.003].You may download, copy and otherwise use the AAM for non-commercial purposes provided that your license is limited by the following restrictions:

(1) You may use this AAM for non-commercial purposes only under the terms of the CC-BY-NCND license.

(2) The integrity of the work and identification of the author, copyright owner, and publisher must be preserved in any copy.

(3) You must attribute this AAM in the following format: [agreed attribution language, including link to CC BY-NC-ND license + Digital Object Identifier link to the published journal article on Elsevier's ScienceDirect ${ }^{\circledR}$ platform].

Este Manuscrito do Autor Aceito para Publicação (AAM) é protegido por direitos autorais e publicado pela Elsevier. Ele esta disponível neste Repositório, por acordo entre a Elsevier e a Universidade de Brasília. As alterações decorrentes do processo de publicação - como a edição, correção, formatação estrutural, e outros mecanismos de controle de qualidade - não estão refletidas nesta versão do texto. A versão definitiva do texto foi posteriormente publicado em [Micron, Volume 40, Número 4, Junho 2009, Pages 419-425, doi:10.1016/j.micron.2009.02.003]. Você pode baixar, copiar e utilizar de outra forma o AAM para fins não comerciais, desde que sua licença seja limitada pelas seguintes restrições:

(1) Você pode usar este AAM para fins não comerciais apenas sob os termos da licença CC- BYNC-ND.

(2) A integridade do trabalho e identificação do autor, detentor dos direitos autorais e editor deve ser preservado em qualquer cópia.

(3) Tem de atribuir este AAM no seguinte formato: [acordo na linguagem atribuída, incluindo o link para CC BY-NC-ND licença Digital + DOI do artigo publicado na revista Elsevier ScienceDirect ${ }^{\circledR}$ da plataforma]. 


\title{
Morphology of the male reproductive system and spermiogenesis in Hypanthidium foveolatum (Alfken, 1930) (Hymenoptera: Apidae: Megachilinae)
}

\author{
I.M.S. Gracielle \\ B.S. Fiorillo \\ J. Lino-Neto \\ S.N. Báo
}

\begin{abstract}
The morphological aspects of male reproductive tract, spermiogenesis and spermatozoa are typical for each species and reflect its evolution, establishing a unique source of characters, which has been used to help solve phylogenetic problems. In Hypanthidium foveolatum the reproductive tract is composed of the testes comprising 28 testicular tubules, deferent ducts, seminal vesicles, accessory glands and an ejaculatory duct. The differentiation of spermatids occurs within cysts of up to 128 germ line cells each one. During the early spermatid phase, the nucleus resembles that of somatic cells. There follows a gradual chromatin condensation with an increase in nuclear electron density. In the spermatozoon, the nucleus contains heterogeneous chromatin with a loose appearance. The acrosome, shaped with the active participation of the Golgi complex, shows an electron-dense perforatorium involved by four electron-lucent acrosomal vesicle projections. The sperm tail presents an axoneme with a $9+9$ + 2 microtubule pattern and two mitochondrial derivatives, which appear with different sizes. A dense crystalloid is formed initially in the mitochondrial matrix of the large derivative. The mitochondrial derivatives' differentiation occurs concomitantly with an axoneme outgrowth. The centriolar adjunct is observed near the axoneme, anterior to the smaller mithocondrial derivative and exhibits an approximately triangular shape in cross-sections. Microtubules were observed around the head region and flagellar components during spermiogenesis.
\end{abstract}

Keywords: Ultrastructure; Spermiogenesis; Spermatozoa; Reproductive tract; Hypanthidium foveolatum; Megachilinae

\section{Introduction}

Bees comprise a group of over 16,000 species (Michener, 2000). They arose sometime in the Cretaceous (Grimaldi, 1999) and have had a long and intimate coevolutionary relationship with flowering plants. Today, they are the most important pollinators of angiosperm plants and many species are economically important crop pollinators (Barth, 1991). Any reduction on the diversity of this group of insects will surely cause an environmental effect due to the disappearance of some vegetal species. However, the more 
direct impact will be on the human food resources, considering that approximately $30 \%$ of this total comes from vegetal species which are in turn pollinated by bees (O'Toole and Raw, 1991).

Currently, bees are considered belong to Apidae (Melo and Gonçalves, 2005) and are divided into seven subfamilies: the long-tongued bees in the subfamilies Megachilinae and Apinae, and the short-tongued bees in the subfamilies Colletinae, Stenotritinae, Andreninae, Halictinae, and Melittinae. The Megachilinae bees are important pollinators in natural and agricultural ecosystems. They have been domesticated in some areas for farming purposes because of their pollinating efficiency, ease of management, and usually rapid increase in populations. These bees adapt to a wide variety of climatic, nesting, and foraging conditions and maintain populations through the presence of predators, parasites, and insecticide poisoning (Leavengood and Serrano, 2005).

In spite of the unquestionable economic and ecological importance of the bees, there are still many controversies about the evolutionary relationships of this group of insects (Dowton and Austin, 1994, Dowton et al., 1997 and Ronquist et al., 1999). Alexander and Michener (1995) provide an attempt to resolve subfamily-level phylogenies using a broad sample of bee subfamilies and tribes and modern cladistic methods. These authors were able to establish the monophyly of many subfamilies (Halictinae, Andreninae, Megachilinae and Apinae) but were unable to resolve clearly the relationships among the subfamilies. For Megachilinae, Roig-Alsina and Michener (1993) resolved the monophyly of the two tribes, Fideliini and Megachilini, but did not clearly resolve relationships among the remaining tribes.

Several of the uncertainties about the evolutionary relationships within Megachilinae and within other bees probably will be resolved with the inclusion of new characters combined with those that are traditionally used (Carcupino et al., 1995 and Jamieson et al., 1999). Some recent studies have demonstrated that the structure and ultrastructure of spermatozoa in Hymenoptera furnish sufficient variations to provide additional characters for cladistic analysis (Quicke et al., 1992, Dallai and Afzelius, 1995, Lino-Neto et al., 1999, Lino-Neto et al., 2000a, Lino-Neto et al., 2000b, Lino-Neto and Dolder, 2001a, Lino-Neto and Dolder, 2001b, Lino-Neto and Dolder, 2002, Zama et al., 2001, Zama et al., 2004, Zama et al., 2005a, Zama et al., 2005b, Zama et al., 2007, Báo et al., 2004, Araújo et al., 2005 and Fiorillo et al., 2005) as has been shown possible in other groups of insects (Baccetti, 1987 and Jamieson et al., 1999). The study of spermiogenesis can also provide new characters for improving the accuracy of hypotheses on phylogenetic relationships.

Considering their informative phylogenetic potential, the structure of the male reproductive tract and the ultrastructural characters of both spermiogenesis and spermatozoa in Hypanthidium foveolatum are herein described providing some additional data that may be 
useful for future studies in taxonomy and phylogeny of Hymenoptera, especially within Megachilinae.

\section{Materials and methods}

Adult virgin males of Hypanthidium foveolatum were collected in the campus of the Federal University of Viçosa, MG, Brazil. For the anatomical analyses, the reproductive systems were observed and photographed under an Olympus CX-31 microscope.

The reproductive tract was dissected and photographed. Testes and Seminal vesicles were separately fixed for $4 \mathrm{~h}$ in a solution containing $2.5 \%$ glutaraldehyde, $3 \%$ sucrose, $0.2 \%$ picric acid and $5 \mathrm{mM} \mathrm{CaCl} 2$ in $0.1 \mathrm{M}$ sodium cacodylate buffer at $\mathrm{pH}$ 7.2. After rinsing in buffer, they were post-fixed with $1 \%$ osmium tetroxide in the same buffer for $1 \mathrm{~h}$. Dehydration was carried out in acetone and embedding in Epon 812 resin. Ultrathin sections, stained with uranyl acetate and lead citrate, were observed by transmission electron microscopy Jeol 1011, operating at $80 \mathrm{kV}$.

\section{Results}

\subsection{Reproductive tract}

The male internal reproductive tract in $\mathrm{H}$. foveolatum comprises two units encapsulated by the scrotal membrane ( Fig. 1A). Each unit is formed by a testis comprising 28 testicular tubules (seminiferous tubules), a deferent duct that forms a seminal vesicle and an accessory gland. The units fuse at their ends flowing into an ejaculatory duct ( Fig. 1B).

Spermiogenesis took place within the testicular tubules. There, multiple cysts are observed containing the spermatogonial lineage in a synchronical maturation process. Some somatic cells (cyst cells) are also scattered amongst the spermatids forming the cysts. Each cyst contains at most 128 spermatids (Fig. 1C). 


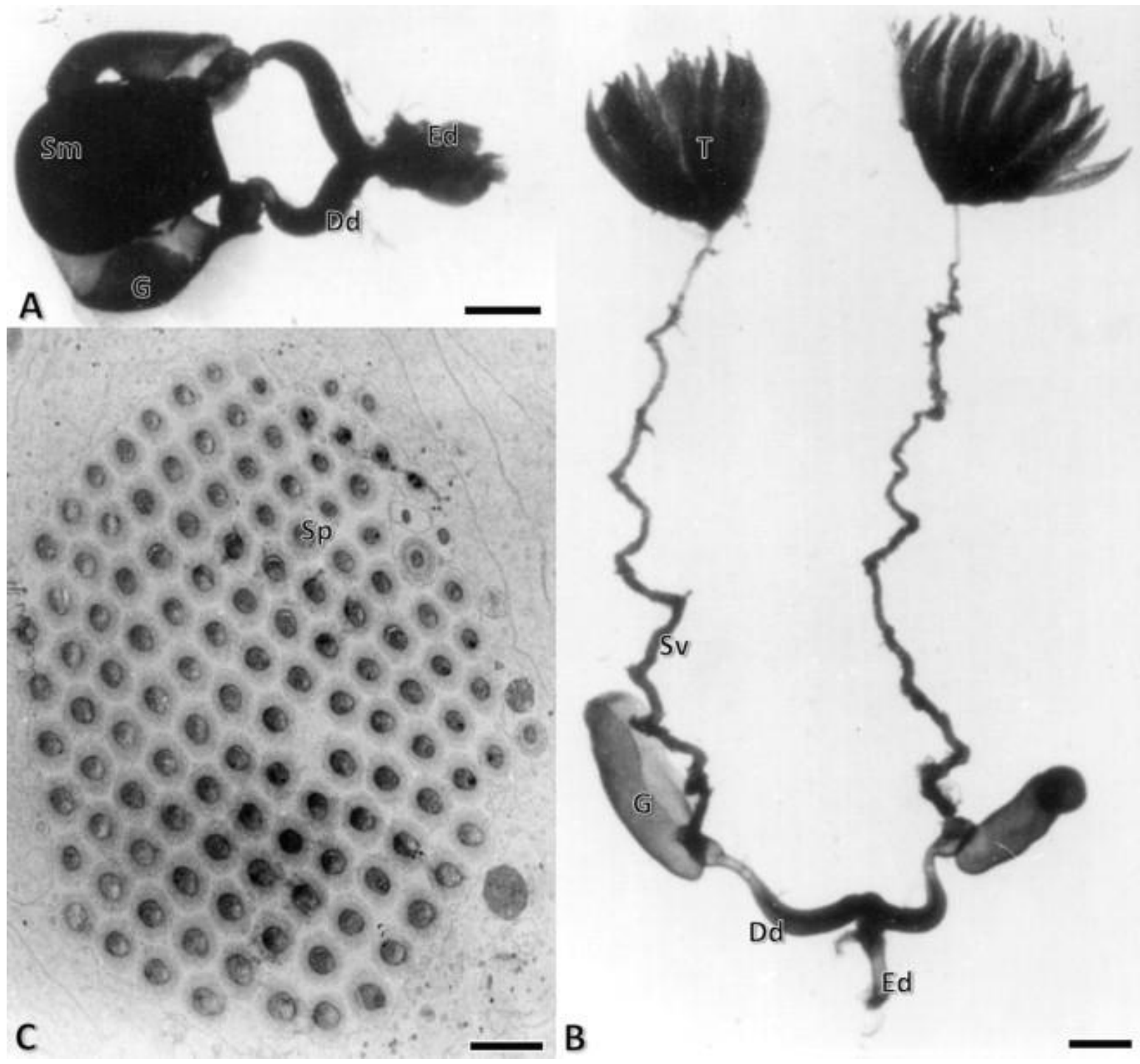

Fig. 1. Male internal reproductive tract of $H$. foveolatum (A) The reproductive tract encapsulated by the scrotal membrane. (B) The two separate units fuse at their ends flowing into the ejaculatory duct. (C) The cyst containing up to 128 spermatozoa. Dd: deferent duct; Ed: ejaculatory duct; G: accessory gland; Sm: scrotal membrane; Sp: spermatid; Sv: seminal vesicle; T: testis. Scale bars: A, B: $500 \mu \mathrm{m}$; C: $0.5 \mu \mathrm{m}$.

\subsection{Spermiogenesis and spermatozoa}

The spermatozoa of $\mathrm{H}$. foveolatum are highly differentiated cells and consist of two morphologically and functionally distinct regions: the head region formed by an acrosomal complex and the nucleus ( Fig. 2A) and the flagellar region that includes an axoneme, a centriolar adjunct, a pair of mitochondrial derivatives and a pair of accessory bodies ( Fig. 3A and $\mathrm{E})$. 


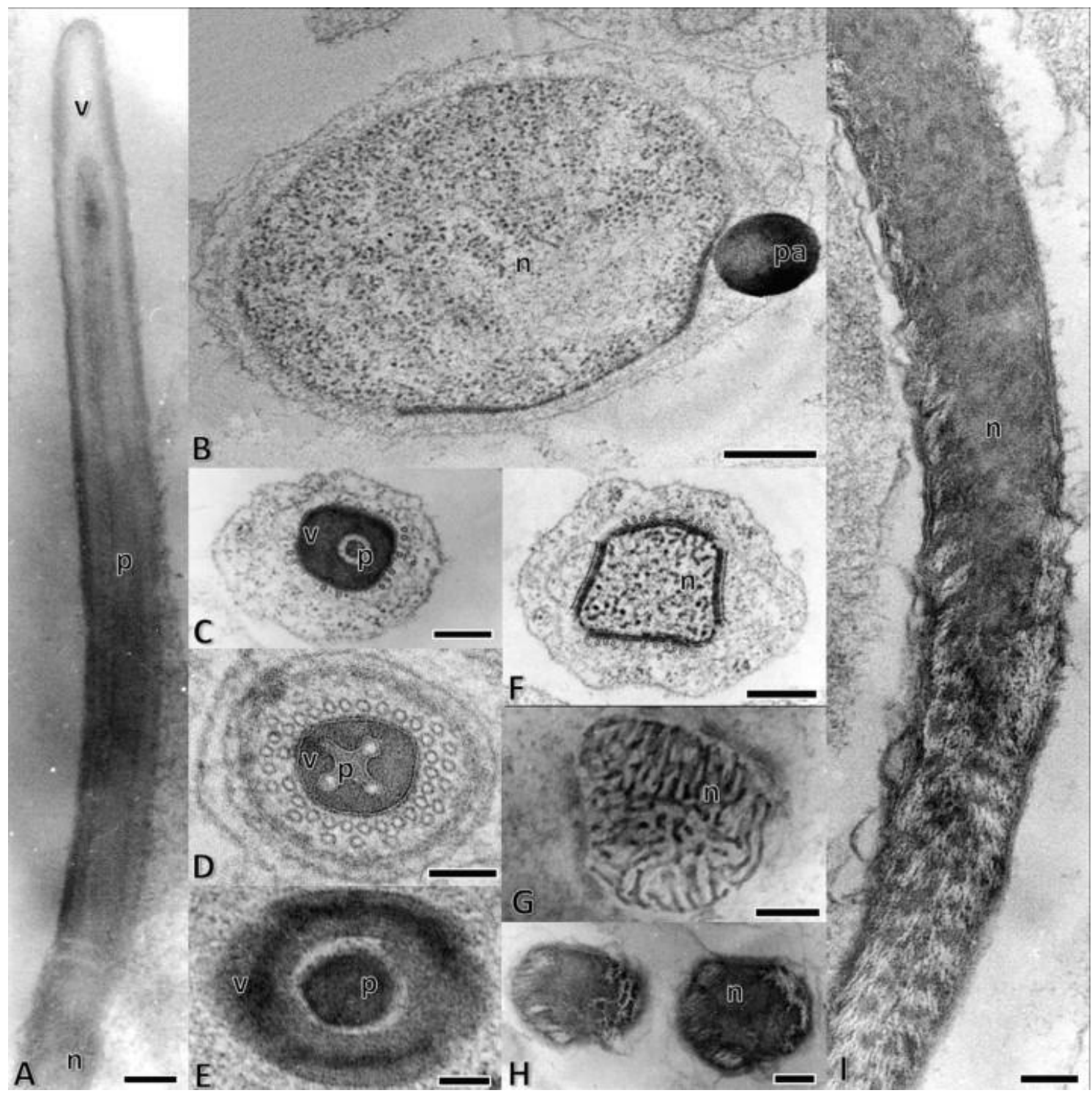

Fig. 2. Electron micrographs of the head region of $H$. foveolatum spermatozoa and spermatids. (A) Longitudinal section of the head region showing the acrosome vesicle and the perforatorium. (B) Transverse head section of spermatid showing proacrosomal vesicle near the nuclear envelope. (C-H) Transverse sections of the head region showing different stages of sperm maturity. The perforatorium is covered by the acrosomal vesicle ( $\mathrm{C}-\mathrm{E}$ ) which becomes more circular as the section nears the tip. The chromatin shows a gradual condensation at the nuclear periphery converging to the nuclear central regions (F-H). (I) Longitudinal section of the nucleus showing a loose appearance. v: acrosomal vesicle; $\mathrm{n}$ : nucleus; p: perforatorium; pa: proacrosomal vesicle. Scale bars: A, D, E, H, I: $0.1 \mu \mathrm{m}$; B: $0.5 \mu \mathrm{m} ; \mathrm{C}, \mathrm{F}$, $\mathrm{G}: 0.2 \mu \mathrm{m}$

During the early spermatid phase, the nucleus resembles that of somatic cells. It shows dispersed chromatin with some electron dense areas. The proacrosomal vesicle, derived from vesicles of the Golgi complex, is observed near the nuclear envelope (Fig. 2B). At this region, the nuclear envelope exhibits a more electron-dense appearance than that of its other regions. In this phase a large number of mitochondria fuse together forming the mitochondrial complex or nebenkern. The axonemal formation begins with a specific $9+2$ arrangement of the 
microtubules in which nine outer doublet microtubules surround a central pair of singlet microtubules.

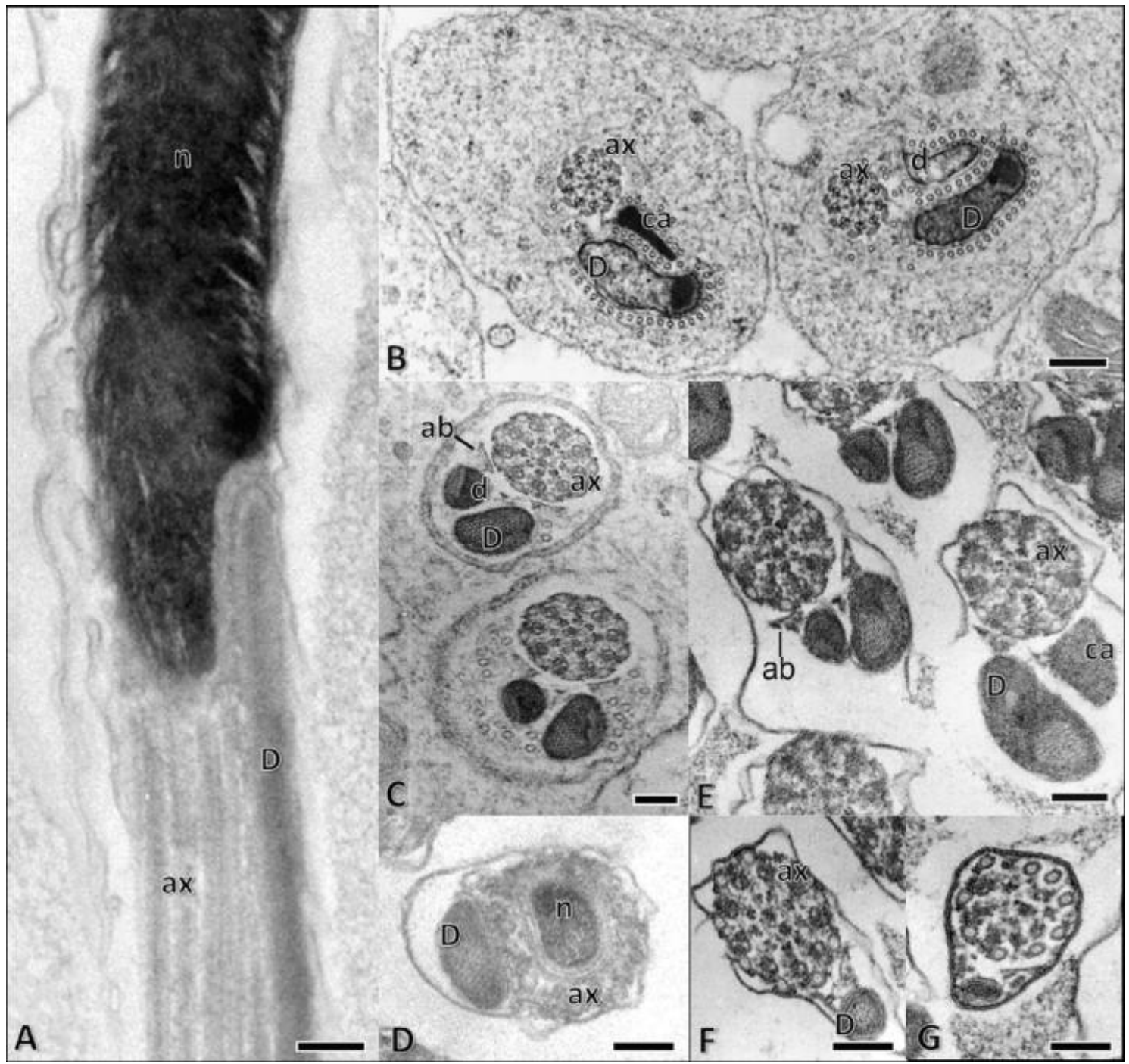

Fig. 3. Electron micrographs of the flagellar region of $\mathrm{H}$. foveolatum spermatozoa and spermatids. (A) Longitudinal section of nucleus-flagellum transition region showing the nuclear projection extending to the beginning of the axoneme. (B-G) Transverse flagellar sections. In a transverse flagellar section of spermatids (B) the presence of manchette microtubules can be observed. The mitochondrial derivatives present asymmetric length and diameter $(C, E)$. In this region, the firsts microtubules can be observed around the nuclear tip (D). In the flagellar posterior portion the smaller mitochondrial derivative ends before the larger one and the axoneme gradually becomes disorganized $(F-G)$. ab: accessory body; ax: axoneme; ca: centriolar adjunct; D: larger mitochondrial derivative; d: smaller mitochondrial derivative; n: nucleus. Scale bars: A, C-G: $0.1 \mu \mathrm{m} ; \mathrm{B}: 0.2 \mu \mathrm{m}$.

During intermediary stages of spermatic maturity there was a gradual condensation of nuclear chromatin with an increase of its electron density. This condensation process begins at the nuclear periphery converging to the central regions (Fig. $2 \mathrm{~F}-\mathrm{H}$ ). During this process, the region near the nuclear envelope, presenting homogeneously condensed chromatin, can be distinguished from the central region of the nucleus with a fibrillar aspect (Fig. 2F). Simultaneously to chromatin condensation and nuclear and cellular elongation, the 
proacrosomal vesicle forms the acrosomic complex, located anteriorly to the nucleus (Fig. 2A). In these stages, a layer of microtubules is observed surrounding the head region (Fig. $2 \mathrm{C}$ and D). In the axoneme the $9+9+2$ pattern is already observed with the nine accessory microtubules (Fig. 3B). The mitochondrial complex turns into two asymmetric mitochondrial derivatives placed close to the axoneme. The larger one exhibits a dense area at the region opposite to the axoneme (Fig. 3B). The centriolar adjunct, located at the nucleus-flagellum transition region and parallel to the large mitochondrial derivative, shows an electron-dense appearance (Fig. 3B).

The fully differentiated spermatozoa of $\mathrm{H}$. foveolatum are elongated cells with wellcondensed chromatin. The acrosome comprises a conical acrosomal vesicle that covers an internal perforatorium ( Fig. 2A). In transverse sections, the acrosome shows an oval profile that becomes more circular as the section nears the tip ( Fig. 2C-E). Cross-sections also revealed the presence of four lateral electron-lucent projections between the acrosomal vesicle and the perforatorium ( Fig. 2D). The transition between the perforatorium base and the anterior portion of the nucleus is visible ( Fig. 2A).

The nucleus is linear and strongly electron-dense but heterogeneously filled with chromatin presenting an incompact appearance (Fig. $2 \mathrm{H}$ and I). It forms a cone shaped projection at its posterior end covered by a thin layer. This projection extends to the beginning of the axoneme, where the first microtubules can be observed in longitudinal and transverse cross-sections respectively (Fig. 3A and D).

The centriolar adjunct is electron-dense, uniformly compact and approximately triangular shaped in cross-sections (Fig. 3E). It begins at the posterior tip of the nucleus and extends parallel to the axoneme and the large mitochondrial derivative and ends above the anterior tip of the smaller derivative.

The axoneme follows the typical pattern of $9+9+2$ arrangement microtubules (Fig. 3C, E and F). The mitochondrial derivatives are asymmetric in both length and diameter with the smaller derivative beginning only in contact with the posterior extremity of the centriolar adjunct (Fig. $3 \mathrm{C}$ and E). Both derivatives have at least two very distinct regions, an electrondense region adjacent to the axoneme and a clear region at the border opposite to the axoneme. The region of paracrystalline material is only present in the larger mitochondrial derivative, located in a region opposite to the axoneme (Fig. $3 \mathrm{C}$ and $\mathrm{E}$ ).

The triangular shaped accessory bodies are observed in transverse sections of the flagellum (Fig. $3 \mathrm{C}$ and E). These structures are located between the axoneme and the mitochondrial derivatives, but do not exist between the axoneme and the centriolar adjunct. 
At the flagellar posterior portion, the smaller mitochondrial derivative ends before the larger one which prolongs up to the axoneme tip and the axoneme gradually becomes disorganized (Fig. 3F and G). The central microtubules finish first, being then followed by the nine doublets and, finally, by the accessory microtubules.

\section{Discussion}

The male reproductive tract of $\mathrm{H}$. foveolatum resembles the pattern structure observed in other bees. According to classification of Ferreira et al. (2004), H. foveolatum comprises type I reproductive apparatus, which was also found in most Colletinae, Andreninae and Halictinae. It is characterized by testes, seminal vesicles and deferent ducts totally or almost encapsulated by the scrotal membrane, forming a globular unit. The type I apparatus is considered basal in phylogeny and the tendency for the other families is towards a higher development of the accessory glands, separation of the encapsulated units and an increase in size and complexity of the ejaculatory duct.

The general morphology of the apparatus has been maintained throughout the order Hymenoptera, but the number of testicular tubules per testis varies considerably among hymenopteran groups. The occurrence of 28 tubules per testis in $\mathrm{H}$. foveolatum differ from the pattern of most basal groups that have three tubules per testis, as occurs in Colletinae, Halictinae, Andreninae and even other Megachilinae as occurs in Anthidium manicatum ( Ferreira et al., 2004). In addition, some other bees present four tubules per testis, such as Mellitinae and Apidae s. stricto ( Roig-Alsina and Michener, 1993), with the exception of Apis mellifera with about 250 tubules (Chapman, 1998).

In $\mathrm{H}$. foveolatum, as in most insects, the development of the germinative cells takes place within cysts ( Phillips, 1970). The cystic organization of spermatogonial lineage cells is also common for Hymenoptera ( Cruz-Landim, 2001). However, the number of spermatids per cyst varies among different species depending on the number of spermatogonial premeiotic divisions ( Oguma et al., 1987, Quagio-Grassioto and Lello, 1996, Cruz-Landim, 2001 and Zama et al., 2007).

During spermiogenesis, the spermatids undergo specific morphofunctional modifications which involve nuclear elongation, chromatin condensation, acrosomal formation, and are accompanied by flagellar development, with axoneme and mitochondrial derivative formation. These events follow the general pattern described for other insect 
groups (Báo, 1996, Báo et al., 1997, Dallai et al., 2001, Dallai et al., 2002 and Dallai et al., 2004).

The participation of Golgi complex in acrosome formation has been reported for some insects (Baccetti, 1975 and Fernandes and Báo, 2001). In the greater part of the insects where this process has been studied, the proacrosomal vesicle, found in early spermatids, is gradually modified, taking on a characteristic elongated shape in the last stages of spermiogenesis (Báo et al., 1989 and Ndiaye and Mattei, 1992).

Sperm nucleus development is characterized by a change from a spherical to an elongated shape. The nuclear material passes through a stage of conversion from a loose to a more compact form. This structural reorganization and high degree of condensation of nuclear material is related to biochemical substitutions. The histones typical of somatic cells, present in early spermatid nuclei, are subsequently substituted by arginine-rich basic proteins (Loir and Lanneau, 1984 and Mello, 1987).

During spermatid-spermatozoon differentiation, numerous cytoplasmic microtubules are involved in the shaping of the cell, and these microtubules are eliminated simultaneously with the cytoplasmic remains at the end of spermiogenesis. Microtubule participation in spermiogenesis has been described for some invertebrates (Ndiaye et al., 1997, Baccetti, 1998, Jamieson et al., 1999 and Chawanji et al., 2007) and for vertebrates (Soley, 1997 and Al-Dhoki, 2004), indicating that they may play an important role in the spermiogenesis process.

The structure of the $\mathrm{H}$. foveolatum spermatozoa is similar to the general description for insect sperm ( Quicke et al., 1992, Newman and Quicke, 1998, Newman and Quicke, 1999a, Newman and Quicke, 1999b, Newman and Quicke, 2000, Lino-Neto et al., 1999, Lino-Neto et al., 2000a, Lino-Neto et al., 2000b, Lino-Neto and Dolder, 2001a, Lino-Neto and Dolder, 2001b, Lino-Neto and Dolder, 2002, Zama et al., 2001, Zama et al., 2004, Zama et al., 2005a, Zama et al., 2005b, Báo et al., 2004 and Fiorillo et al., 2005). They are linear, long and slender as which is observed for the majority of the Hymenoptera.

The bilayered acrosome is frequently found in other Hymenoptera. It was described for Symphyta (Quicke et al., 1992 and Newman and Quicke, 1999a), parasitic wasps (Lino-Neto and Dolder, 2001a), ants (Wheeler et al., 1990 and Lino-Neto and Dolder, 2002) and for bees (Peng et al., 1993, Zama et al., 2001, Zama et al., 2004, Zama et al., 2005a, Zama et al., 2005b, Báo et al., 2004 and Fiorillo et al., 2005). The presence of four acrosomal vesicle lateral projections along the perforatorium is not observed in other Hymenoptera already examined. However, it is similar to the three projections observed in Meliponini (Zama et al., 2004).

The mature nucleus presenting a loose chromatin differs from the Hymenoptera pattern, but it was also observed in Halictinae (Fiorillo et al., 2005), and in some Meliponini 
(Zama et al., 2004). The nuclear base penetrating into the beginning of the axoneme has also been observed in Apinae (Peng et al., 1993 and Lino-Neto et al., 2000b) and Vespidae (Mancini et al., 2006). However, it is uncommon for the vast majority of Apoidea, which have the nuclear base finishing in a short cone above the axonemal implantation (Zama et al., 2001, Zama et al., 2004, Zama et al., 2005a, Zama et al., 2005b, Báo et al., 2004 and Fiorillo et al., 2005).

The asymmetry in length and diameter of the mitochondrial derivatives is common for most Apoidea (Lino-Neto et al., 2000b; Zama et al., 2001, Zama et al., 2004, Zama et al., 2005a, Zama et al., 2005b, Báo et al., 2004 and Fiorillo et al., 2005), Vespidae (Mancini et al., 2006), and some Symphyta (Newman and Quicke, 1999a). Furthermore, the mitochondrial regions in H. foveolatum are very similar to those described for other Apoidea ( Lino-Neto et al., 2000b; Zama et al., 2001, Zama et al., 2004, Zama et al., 2005a, Zama et al., 2005b, Araújo et al., 2005 and Fiorillo et al., 2005).

The arrangement observed in the axoneme with $9+9+2$ microtubules is the pattern for Aculeata with the central microtubules and the nine doublets terminating first, followed by the accessory microtubules (Lino-Neto et al., 2000b, Zama et al., 2001, Zama et al., 2004, Zama et al., 2005a, Zama et al., 2005b, Zama et al., 2007, Báo et al., 2004, Araújo et al., 2005, Fiorillo et al., 2005 and Mancini et al., 2006).

Based on the characteristics compared above, the spermatozoa of $\mathrm{H}$. foveolatum are, for the most part, similar to the majority of the Hymenoptera (Jamieson et al., 1999). However, some distinct differences were found: the number of projections at the anterior portion of the acrosomal vesicle, the presence of some areas of loose chromatin along the nucleus and at the nuclear base penetrating into the beginning of the axoneme. Furthermore, the occurrence of 28 tubules per testis in $\mathrm{H}$. foveolatum differ from all basal groups so far examined which present three tubules per testis. Thus, these characteristics corroborate data of the structural diversity of hymenopteran male reproductive tract and spermatozoa, which might provide a character system that can be used, in association with other systems, to resolve various uncertainties about the evolutionary relationships of this insect group.

\section{Acknowledgements}

This research was supported by Conselho Nacional de Desenvolvimento Científico e Tecnológico (CNPq) to research fellowships to S.N. Báo and "Iniciação Científica" fellowships to I.M.S. Gracielle; Fundação de Empreendimentos Científico e Tecnológico (FINATEC), Coordenação de Aperfeiçoamento de Pessoal de Nível Superior (CAPES) and Financiadora de Estudos e Projetos (FINEP). 


\section{REFERENCES}

Al-Dhoki, O.A., 2004. Electron microscopic study of sperm head differentiation in the Arabian horned viper Cerastes cerastes (Squamata, Reptilia). J. Biol. Sci. 4,111-116.

Alexander, B.A., Michener, C.D., 1995. Phylogenetic studies of the families of shorttongued bees (Hymenoptera, Apoidea). Univ. Kansas Sci. Bull. 55 (11), 377-424.

Arau' jo, V.A., Zama, U., Dolder, H., Lino-Neto, J., 2005. Morphology and ultrastructure of the spermatozoa of Scaptotrigona xanthotricha Moure (Hymenoptera, Apidae, Meliponini). Braz. J. Morphol. Sci. 22, 137-141.

Baccetti, B., 1975. The role of the Golgi complex during spermiogenesis. Curr. Top. Dev. Biol. 10, 103-122.

Baccetti, B., 1987. Spermatozoa and phylogeny in orthopteroid insects. In: Baccetti, B.M. (Ed.), Evolutionary Biology of Orthopteroid Insects. John Wiley and Sons, New York, pp. 12-112.

Baccetti, B., 1998. Spermatozoa. In: Harrison, F.W., Locke, M. (Eds.), Microscopic Anatomy of Invertebrates 11C, Insecta. Wiley-Liss, New York, pp. 843-894.

Báo, S.N., 1996. Spermiogenesis in Coelomera lanio (Chrysomelidae, Gallerucinae): ultrastructural and cytochemical studies. In: Jolivet, P.H.A., Cox, M.L. (Eds.), Chrysomelidae Biology, General Studies. v.3, pp. 119-132.

Báo, S.N., Quagio-Grassioto, I., Dolder, H., 1989. Acrosome formation in Ceratitis capitata (Diptera, Tephritidae). Cytobios 58, 93-100.

Báo, S.N., Kitajima, E.W., Callaini, G., Lupetti, P., Dallai, R., 1997. Spermiogenesis in three species of whitefly (Homoptera, Aleyrodidae). Acta Zool. 78, 163-170.

Báo, S.N., Simo es, D.G., Lino-Neto, J., 2004. Sperm ultrastructure of the bees Exomalopsis (Exomalopsis) auropilosa Spinola 1983 and Paratetrapedia (Lophopedia) sp. Michener and Moure 1957 (Hymenoptera, Apidae, Apinae). J. Submicrosc. Cytol. Pathol. 36, 23-28.

Barth, F.G., 1991. Insects and Flowers: The Biology of a Partnership. Princeton University Press, Princeton, New Jersey.

Carcupino, M., Profili, G., Kathirithamby, J., Mazzini, M., 1995. Sperm ultrastructure of Xenos vesparum (Rossi) and its significance in the taxonomy and phylogeny of Strepsiptera (Insecta). Mem. Mus. Nat. Hist. Nat. 166, 291-296.

Chapman, R.F., 1998. The Insects: Structure and Function, 4th ed. University Press, Cambridge.

Chawanji, A.S., Hodgson, A.N., Villet, M.H., Sanborn, A.F., Phillips, P.K., 2007. Spermiogenesis in three species of cicadas (Hemiptera, Cicadidae). Acta Zool. 88 (4), 337-348.

Cruz-Landim, C., 2001. Organization of the cysts in bee (Hymenoptera, Apidae) testis: Number of spermatozoa per cyst. Iheringia. Se' r. Zool. 91, 183-189. 
Dallai, R., Afzelius, B.A., 1995. Phylogenetic significance of axonemal ultrastructure: examples from Diptera and Trichoptera. Mem. Mus. Nat. Hist. Nat. 166, 301-310.

Dallai, R., Lupetti, P., Frati, F., Nardi, F., Afzelius, B.A., 2001. Sperm ultrastructure and spermiogenesis in the relic species Tricholepidion gertschi Wygodzinsky (Insecta, Zygentoma). Tissue Cell 33, 596-605.

Dallai, R., Lupetti, P., Carapelli, A., Frati, F., Afzelius, B.A., 2002. Sperm structure and spermiogenesis in Atelura formicaria Heyden (Zygentoma, Insecta). Acta Zool. 83, 245-262.

Dallai, R., Carapelli, A., Nardi, F., Fanciulli, P.P., Lupetti, P., Afzelius, B.A., Frati, F., 2004. Sperm structure and spermiogenesis in Coletinia sp. (Nicoletiidae, Zygentoma, Insecta) with a comparative analysis of sperm structure in Zygentoma. Tissue. Cell 36, 233-244.

Dowton, M., Austin, A.D., 1994. Molecular phylogeny of the insects order Hymenoptera: Apocritan relationships. Proc. Natl. Acad. Sci. U.S.A. 91, 9911-9915.

Dowton, M., Austin, A.D., Dillon, N., Bartowsky, E., 1997. Molecular phylogeny of the apocritan wasps: the Proctotrupomorpha and Evaniomorpha. Syst. Ent. 22, 245-255.

Fernandes, A.P., Báo, S.N., 2001. Ultrastructural studies on spermiogenesis and spermatozoa of insect pests (Hemiptera, Pentatomidae). Curr. Res. Adv. Agric. Entomol. 1, 13-38.

Ferreira, A., Abdalla, F.C., Kerr, W.E., Cruz-Landim, C., 2004. Systematics, morphology and physiology. Comparative anatomy of the male reproductive internal organs of 51 species of bees. Neotrop. Entomol. 33, 569-576.

Fiorillo, B.S., Coelho, A.A.M., Lino-Neto, J., Báo, S.N., 2005. Structure and ultrastructure of the spermatozoa of Halictidae (Hymenoptera, Apoidea). J. Submicrosc. Cytol. Pathol. 37, 75-81.

Grimaldi, D., 1999. The co-radiations of pollinating insects and angiosperms in the Cretaceous. Ann. Mo. Bot. Gard. 86, 373-406.

Jamieson, B.G.M., Dallai, R., Afzelius, B.A., 1999. Insects: Their Spermatozoa and Phylogeny. Scientific Publishers, Enfield, New Hampshire, 555.

Leavengood Jr., J.M., Serrano, D., 2005. A distributional checklist of the Leaf-cutting bees (Hymenoptera, Megachilidae) of Florida. Insecta Mundi 19, 172-176.

Lino-Neto, J., Dolder, H., 2001a. Redescription of sperm structure and ultrastructure of Trichogramma dendrolini (Hymenoptera, Chalcidoidea, Trichogrammatidae). Acta Zool. 82, 159-164.

Lino-Neto, J., Dolder, H., 2001b. Structural characteristics of the spermatozoa of Scelionidae (Hymenoptera, Platygastroidea) with phylogenetic considerations. Zool. Sci. 30, 89-96.

Lino-Neto, J., Dolder, H., 2002. Sperm structure and ultrastructure of the fire ant Solenopsis invicta (Buren) (Hymenoptera, Formicidade). Tissue Cell 34, 124-128.

Lino-Neto, J., Báo, S.N., Dolder, H., 1999. Structure and ultrastructure of spermatozoa of Bephratelloides pomorum (Fabricius) (Hymenoptera, Euritomidae). Int. J. Ins. Morphol. Embryo 28, 253-259. 
Lino-Neto, J., Báo, S.N., Dolder, H., 2000a. Structure and ultrastructure of spermatozoa of Trichogramma pretiosum Riley and Trichogramma atopovirilia Oatma and Platner (Hymenoptera, Trichogrammatidae). Acta Zool. 81, 205-211.

Lino-Neto, J., Báo, S.N., Dolder, H., 2000b. Sperm ultrastructure of the honey bee (Apis mellifera) (L) (Hymenoptera, Apidae) with emphasis on the nucleus-flagellum transition region. Tissue Cell 32, 322-327.

Loir, M., Lanneau, M., 1984. Structural function of the basic nuclear proteins in ram spermatids. J. Ultrastruct. Res. 86, 262-272.

Mancini, K., Lino-Neto, J., Dolder, H., 2006. Sperm ultrastructure of Agelaia vicina (Hymenoptera, Vespidae). Insect. Soc. 53, 333-338.

Mello, M.L.S., 1987. Nuclear cytochemistry and polarization microscopy of the spermatozoa of Triatoma infestans Klug. Z. Mikrosk. Anat. Forsch. 101, 245-250.

Melo, G.A.R., Gonc,alves, R.B., 2005. Higher-level bee classifications (Hymenoptera, Apoidea, Apidae sensu lato). Rev. Bras. Zool. 22, 153-159.

Michener, C.D., 2000. The Bees of the World. Johns Hopkins University Press, Baltimore, 913.

Ndiaye, M., Mattei, X., 1992. Particularity of acrosome formation during spermiogenesis in two mosquitoes: Toxorbynchites brevipalpis and Anopheles gambiae. J. Submicrosc. Cytol. Pathol. 24 (2), 269-272.

Ndiaye, M., Mattei, X., Thiaw, O.T., 1997. Ultrastructural diversity of the manchette in spermatids of mosquitoes (Diptera, Culicidae). Acta Zool. 78, 47-49.

Newman, T.M., Quicke, D.L.J., 1998. Sperm development in the imaginal testes of Aleiodes coxalis (Hymenoptera, Braconidae, Rogadinae). J. Hym. Res. 7, 25-37.

Newman, T.M., Quicke, D.L.J., 1999a. Ultrastructure of imaginal spermatozoa of sawflies (Hymenoptera, Symphyta). J. Hym. Res. 8, 35-47.

Newman, T.M., Quicke, D.L.J., 1999b. Ultrastructure of spermatozoa in Leptopilina (Hymenoptera, Cynipoidea, Eucoilidae). J. Hym. Res. 8, 197-203.

Newman, T.M., Quicke, D.L.J., 2000. Sperm development and ultrastructure of mature spermatozoa of Megalyra (Hymenoptera, Megalyroidea). J. Hym. Res. 9, 62-70.

O’Toole, C., Raw, A., 1991. Bees of the World. Sterling Publishing Co., New York, USA.

Oguma, Y., Kurokawa, H., Kusama, T., 1987. Number of primary spermatocytes in the Drosophila immigrans (Sturtevant) group (Diptera: Drosophilidae). Int. J. Insect Morph. Embryol. 16, 85-89.

Peng, C.Y.S., Yin, C.M., Yin, L.R.S., 1993. Ultrastructure of honey bee, Apis mellifera, sperm with special emphasis on the acrosomal complex following high-pressure freezing fixation. Physiol. Entomol. 18, 93-101.

Phillips, D.M., 1970. Insect sperm: their structure and morphogenesis. J. Cell Biol. 44, 243-277. 
Quagio-Grassioto, I., Lello, E., 1996. Cytoplasmic bridges, intercellular junctions, and individualization of germ cells during spermatogenesis in Dermatobia hominis (Diptera, Cuterebridae). J. Morphol. 227, 145-154.

Quicke, D.L.J., Ingram, S.N., Baillie, H.S., Gaitens, P.V., 1992. Sperm structure and ultrastructure in the Hymenoptera (Insecta). Zool. Sci. 21, 381-402.

Roig-Alsina, A., Michener, C.D., 1993. Studies of the phylogeny and classification of longtongued bees (Hymenoptera, Apoidea). Univ. Kansas Sci. Bull. 55, 123-173.

Ronquist, F., Rasnitsyn, A.P., Roy, A., Eriksson, K., Lindgren, M., 1999. Phylogeny of Hymenoptera: a cladistic reanalysis of the Rasnitsyn's data. Zool. Sci. 28, 13-50.

Soley, J.T., 1997. Nuclear morphogenesis and the role of the manchette during spermiogenesis in the ostrich (Struthio camelus). J. Anat. 190, 563-576.

Wheeler, D.E., Crichton, E.G., Krutzsch, P.H., 1990. Comparative ultrastructure of ant spermatozoa (Formicidae, Hymenoptera). J. Morphol. 206, 343-350.

Zama, U., Lino-Neto, J., Dolder, H., 2001. Ultrastructure of spermatozoa in Plebeia (Plebeia) droyana (Hymenoptera, Apidae, Meliponina). J. Hym. Res. 10, 261-270.

Zama, U., Lino-Neto, J., Dolder, H., 2004. Structure and ultrastructure of spermatozoa in Meliponini (stingless bees) (Hymenoptera: Apidae). Tissue Cell 36, 29-41.

Zama, U., Lino-Neto, J., Melo, S.M., Campos, L.A.O., Dolder, H., 2005a. Ultrastructural characterization of spermatozoa in Euglossine bees (Hymenoptera, Apidae, Apinae). Insect. Soc. 52, 122-131.

Zama, U., Brito, P., Lino-Neto, J., Campos, L.A.O., Dolder, H., Báo, S.N., 2005b. The sperm morphology of mud dauber Sceliphron fistularium Dahlbom (Hymenoptera, Apoidea, Sphecidae), as an indicative of bees relation. J. Submicrosc. Cytol. Pathol. 37, 91-99.

Zama, U., Moreira, J., Báo, S.N., Campos, L.A.O., Dolder, H., Lino-Neto, J., 2007.

Morphology of testicular and post-testicular spermatozoa in Microstigmus arlei Richards, 1972 and M. nigrophthalmus Melo, 1992 (Hymenoptera, Apoidea, Pemphredoninae) with phylogenetic consideration. Arth. Struct. Dev. 36, 304-316. 